\title{
Prevalence of Trypanosoma Evansi in Dromedary Camels (Camelus dromedarius) and Its Possible Mechanical Vectors in Al Kharj Town, Riyadh Region, Saudi Arabia
}

\author{
Mohamed El Wathigi*, Ali Al Massud ${ }^{2}$, A Rahman $^{3}$ and Bernard Faye ${ }^{4}$ \\ ${ }^{1}$ Animal Quarantine of Jeddah Islamic Port, (MEWA) KSA \\ ${ }^{2}$ Conservation and Genetic Improvement Center Al-Kharj, Saudi Arabia \\ ${ }^{3}$ Veterinary Research Institute, Khartoum, Sudan
}

${ }^{4}$ CIRAD-ES, UMR SELMET 34398 Montpellier Cedex, France

*Corresponding author: Mohamed El Wathig Animal Quarantine of Jeddah Islamic Port, (MEWA) KSA

\begin{abstract}
Trypanosomosis is the most important single cause of economic losses in camels. The present study was conducted to determine the prevalence of camel trypanosomosis and its vectors in Al-Kharj, Central Province, Saudi Arabia. One hundred and seven serum samples were examined to detect the presence of T. evansi infection by CATT test. Eight Nzi traps for sampling of biting flies were deployed in camel farms, including water station, people residence, cactus farm (Aloe vera), irrigated areas, open Range, cowsheds, sheep pens, and control. Camel trypanosomosis prevalence was $21.5 \%$ during the study period. The highest catches of flies were around water station and people residence. The blood biting flies caught were Stomoxys calcitrans and some mosquito's species. Stomoxys calcitrans may be an important mechanical vector of camel trypanosomosis in the study area. The peak of muscidae abundance was observed in March, April and October.
\end{abstract}

Keyword: CATT/T.evansi; Stomoxys calcitrans; Dromedary; Nzi traps, Seasonal variation; Al Kharj

\section{Introduction}

Camel trypanosomosis, also known as Surra, is one of the main diseases of camels. It is caused by Trypanosoma evansi, causing morbidity of up to $30 \%$ and mortality of around 3\% Pacholek et al. [1]. The disease is known in Saudi Arabia as heyam Al-Qarawi et al. [2]. Mechanical transfer by haematophage biting flies such as tabanids and Stomoxys spp is the main mode of transmission of T.evansi from infected host to another one Losos [3]; Luckins[4]. There are several traps designs used for catching biting flies. One of the efficient types of traps used for catching Stomoxys is called Nzi (Swahili name for fly) which is also a very effective trap for stable flies and horse flies Mihok et al. [5]. In addition, attractants such as carbon dioxide (CO2) may improve capture rates, but relative responses to different attractants may vary among species Schofield et al., [6]; Beresford and Sutcliffe [7]. Acetone may be useful for increasing catches of Stomoxys species under certain conditions or release rates Mihok et al, [8].Therefore, the objective of the current study is to determine camel trypanosomosis prevalence in Al Kharj around camel farm, Saudi Arabia and to update the base line data available for the distribution of biting flies in the study area.

\section{Materials and Methods}

\section{Study area:}

This study was conducted in Al-Kharj town, Central Province of Saudi Arabia $\left(24^{\circ} 8^{\prime} \mathrm{N}\right.$ and $\left.47^{\circ} 18^{\prime} \mathrm{E}\right)$, during the period, January to October 2016 .The climate in the study area is characterized by hot dry season (May-September) and a cool season (October-March) with few rain showers in the cool season, (Table 1).

\section{Collection and process of samples:}

Convenience sampling was employed in this study Thrusfield [9], according to the availability of the camel herds. In the present survey, 107 camel's blood samples were collected from different locations in the area (local herds in 8 locations) at the beginning of the study (i.e. in February). Blood samples were collected in 
plain vacutainers and centrifuged at $5000 \mathrm{rpm}$ for 15 minutes after clotting to separate serum for CATT/ test. A CATT Trypanosoma evansi kit produced by Institute of Tropical Medicine (Prince Leopold) Antwerpen, Belgium was used to screen camel sera collected in this study. The test utilizes a CATT -antigen of a freezedried suspension of purified, fixed and stained bloodstream form trypanosomes expressing a predominant variable antigen type of Trypanosoma evansi (Ro Tat 1.2). The test is conducted on a plastified card according to Manufacturer instructions.

\section{Collection of biting flies}

Eight NZI traps (per farm), 1-m triangular traps made from phthalogen blue, black cotton, and white polyester mosquito netting Mihok [10], were used for sampling of biting flies (Figure 1). The Nzi trap was designed for tsetse, stable flies and tabanids, Mihok et al. [5].The trapping sites selected for sampling flies were camel's barns, water station, people residence, cactus farm (Aloe vera), irrigated areas, open Range, sheep pens and one Nzi trap without an attractant.

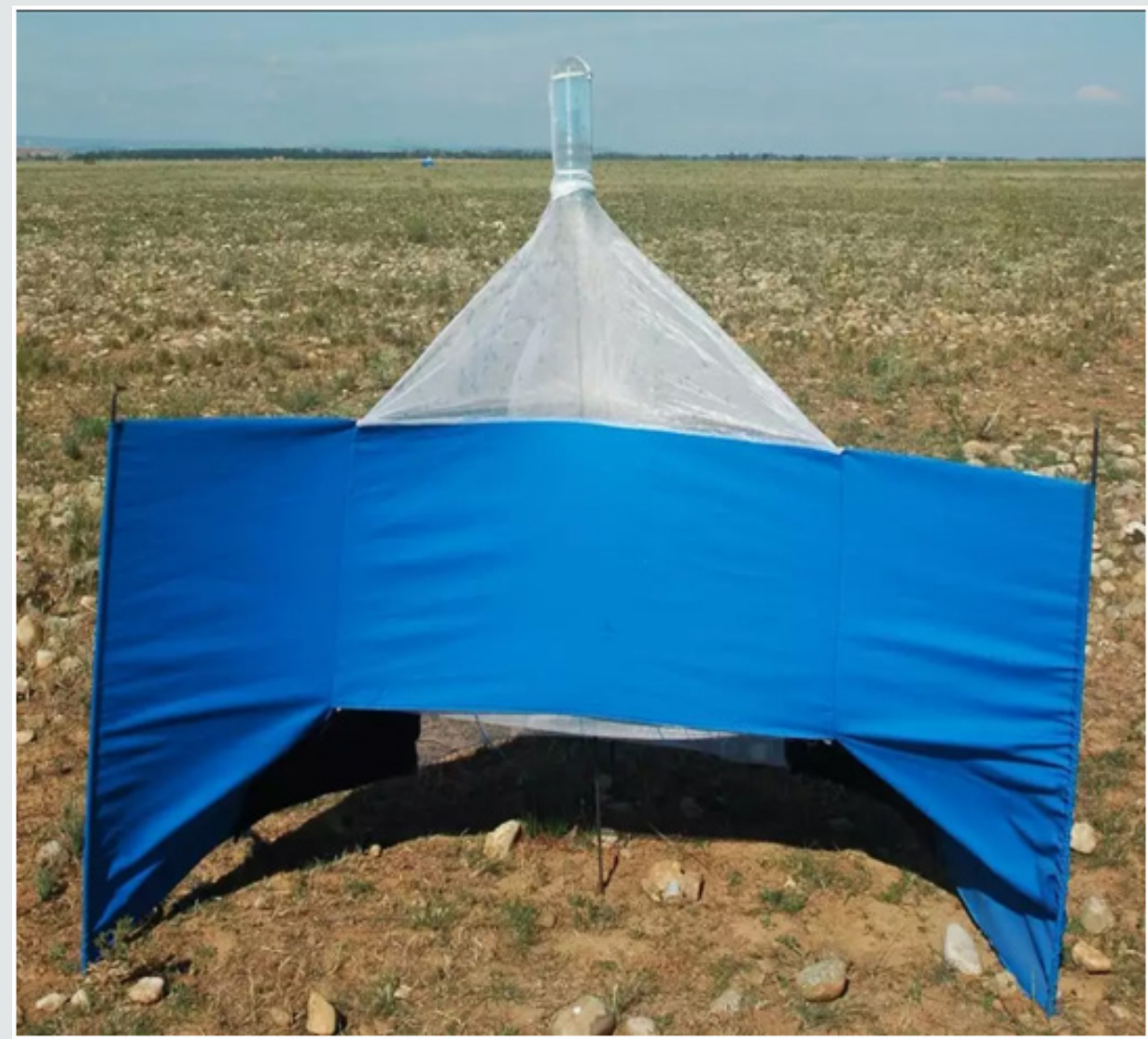

Figure 1: NZI Trap diploid in Al-Kharj, Saudi Arabia.

\section{Attractants}

Carbon Dioxide (CO2) and acetone were used as attractants. CO2 was released from cylinders situated near traps at a release rate of $200 \mathrm{ml} / \mathrm{h}$ via a regulator. The traps were baited with acetone (SIGMA-ALDRICH chemie $\mathrm{GmbH}$ ) in $20 \mathrm{ml}$ vials and the container caps were punctured with a nail. The evaporation rate was $150 \mathrm{mg} / \mathrm{h}$ and the vials were placed on the ground near each trap.

\section{The Survey Design}

In each site, the NZI traps were deployed for a period of three days every month from February to October. The three months of winter (November to January) were not included in the study because problems impeding work. CO2 was turned on at 09:00 hours each morning and was turned off at 13: 30 hours. The flies were collected daily at 8:00 h, then were taken to the laboratory and killed by chilling at $-20 \mathrm{o} C$ for one hour. Flies from all collected traps were preserved in $70 \%$ alcohol. All flies captured in the traps were counted and identified according to Zumpt [11].For confirmation, samples from the flies were sent in the screw-top bottles with alcohol to the Entomology Department, Faculty of Food and Agriculture, King Saud University for further identification.

\section{Meteorological data}

Data regarding rainfall in Kharj region were provided by Weather for Riyadh, Saudi Arabia (internet)" Weather base" Retrieved on November 2016. (Table1). Statistical Analysis. Graph-Pad prism (windows version7.03) software was used for entomological data analysis (different trap sites, climate variables and the total numbers of muscids and mosquitoes). The relationship between insects' abundance and rainfall was investigated by using Pearson's correlation. For this analysis, XLstat software (Addinsoft (C) was used. 
Table 1: The climate data for Kharj, Riyadh region 2016.

\begin{tabular}{|c|c|c|c|c|c|c|c|c|c|c|c|c|c|}
\hline Month & Jan & Feb & Mar & Apr & May & Jun & Jul & Aug & Sep & Oct & Nov & Dec & Year \\
\hline Record high ${ }^{\circ} \mathrm{C}\left({ }^{\circ} \mathrm{F}\right)$ & 33 & 36 & 38 & 43 & 47 & 53 & 48 & 47 & 45 & 43 & 36 & 32 & 53 \\
& 92 & 97 & 101 & 109 & 117 & 128 & 119 & 116 & 113 & 109 & 97 & 90 & 128 \\
\hline Average high ${ }^{\circ} \mathrm{C}\left({ }^{\circ} \mathrm{F}\right)$ & 19 & 23 & 27 & 32 & 38 & 41 & 43 & 42 & 40 & 34 & 27 & 22 & 32 \\
& -67 & 74 & 80 & 90 & 101 & 106 & 109 & 108 & 104 & 94 & 81 & 71 & 90 \\
\hline Daily mean ${ }^{\circ} \mathrm{C}\left({ }^{\circ} \mathrm{F}\right)$ & 14 & 17 & 21 & 27 & 32 & 34 & 36 & 36 & 33 & 28 & 22 & 17 & 26 \\
\hline Average low ${ }^{\circ} \mathrm{C}\left({ }^{\circ} \mathrm{F}\right)$ & -58 & -62 & -70 & -80 & -90 & -94 & -97 & -96 & -91 & -82 & -71 & -62 & -79 \\
\hline Record low & $\circ$ \\
& 11 & 15 & 21 & 26 & 28 & 29 & 27 & 26 & 20 & 16 & 11 & 9 & 20 \\
\hline Average precipitation cm & -52 & -59 & -69 & -78 & -83 & -84 & -81 & -78 & -68 & -60 & -52 & -48 & -68 \\
\hline (inches) & -1 & 0 & 5 & 11 & 17 & 20 & 22 & 22 & 16 & 12 & 7 & 2 & -1 \\
\hline & -30 & -32 & -41 & -52 & -63 & -68 & -72 & -72 & -61 & -54 & -45 & -35 & -30 \\
\hline
\end{tabular}

\section{Results}

Based on CATT results, the prevalence of T. evansi infection in camels was $21.5 \%$. A total of 451 insects (401 flies and 50 mosquitoes) were caught in the traps during the study period (Feb.2016-October 2016). Among these insects, no Tabanid flies were present. The traps caught flies that belonged to 7 families and 17 species (Table 2). The majority of the species belonged to the family Muscidae: 60\% were Musca domestica and 17\% Musca sorbens among which Stomoxys calcitrans (Figure 2) representing $6 \%$ of the capture, was the only biting fly species. Few numbers of mosquitoes (Diptera: Culicidae) were caught in the NZI traps compared to muscidae. A peak of abundance was observed for both muscids and mosquitoes in March and April A second peak was observed in October (Figure 3). A high correlation between abundance of insects caught in the traps and rainfall was observed ( $r=0.942 ; p<0.0001)$. The higher catches of flies as well as mosquitoes were in the water station and around people residence. The lower catches were in cactus farm (Aloe vera), irrigated areas, and open range respectively (Figure 4). However, 21\% of the mosquitoes were caught in the control trap. The peak of seasonal activity of muscids and mosquitoes was in March and April (i.e. after the end of the rainy season in Al-Riyadh region) as shown in the (Figure 5).

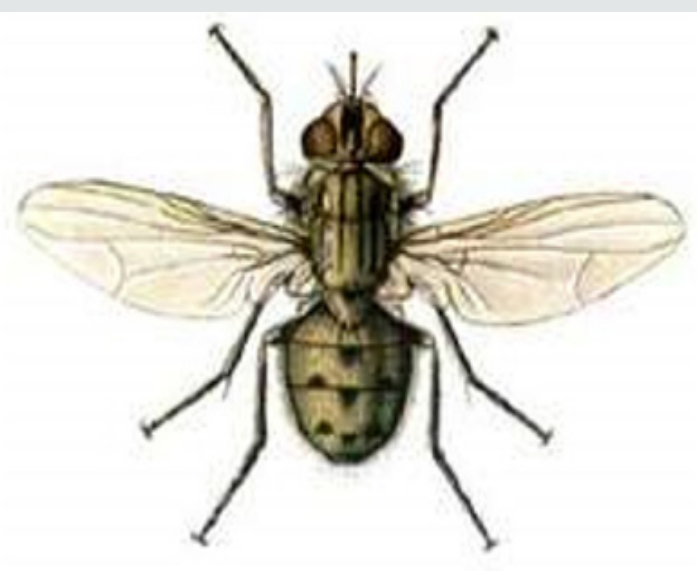

Figure 2: Stomoxys calcitrans.

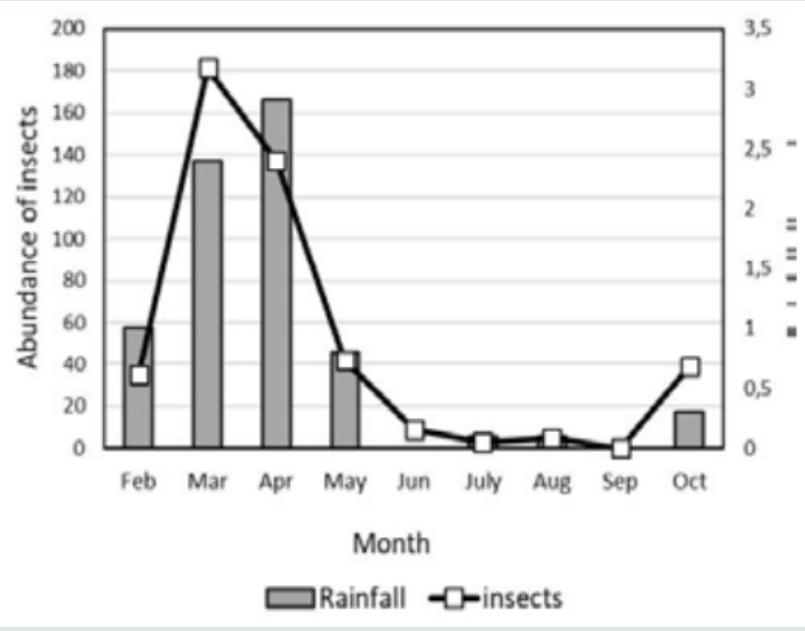

Figure 3: Relationships between abundance insects caught in traps and monthly rainfall in Kharj region (Saudi Arabia) for the year 2016.

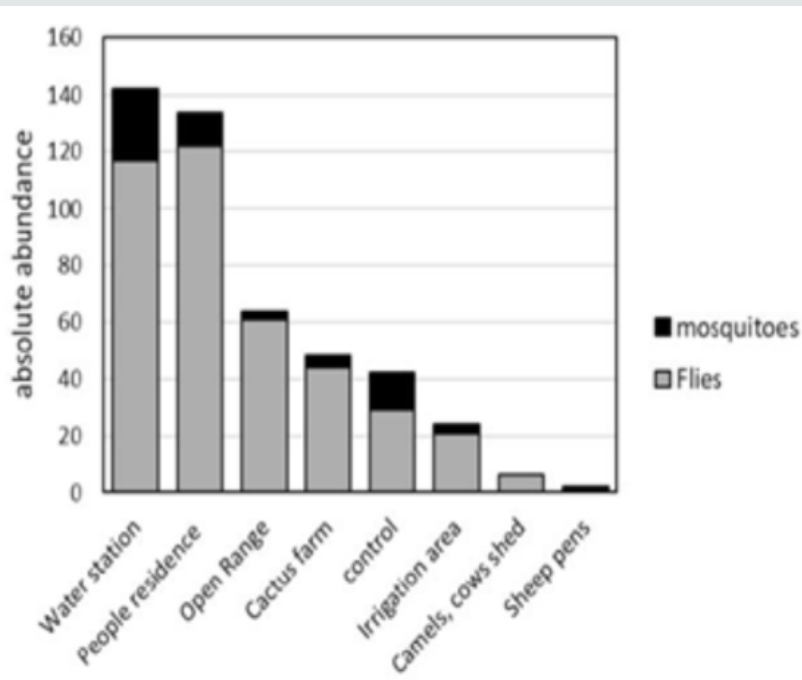

Figure 4: Total trap catches from different sites in Al-Kharj, Riyadh Region 2016. 


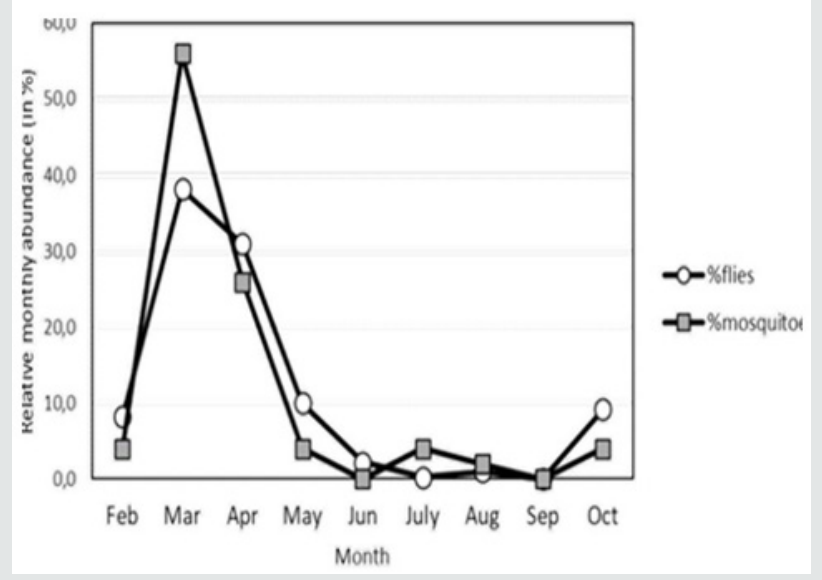

Figure 5: Monthly relative abundance of Muscidae and Mosquitoes in Al-Kharj, Riyadh Region.

Table 2: The catch composition of flies attracted to NZI traps in Al -Kharj, Al- Riyadh Region 2016.

\begin{tabular}{|c|c|c|c|}
\hline Family & Species & \multicolumn{2}{|c|}{ Reference } \\
\hline Muscidae & $\begin{array}{c}\text { Stomoxys } \\
\text { calcitrans } \\
\text { Musca domestica } \\
\text { Musca calleva } \\
\text { Musca } \\
\text { crassirostris } \\
\text { Coenosia } \\
\text { attenuata } \\
\text { Musca sorbens } \\
\text { Musca biseta } \\
\text { Lispe sp. }\end{array}$ & $\begin{array}{r}\text { Linnaeus } \\
\text { Linnaeus } \\
-18 \\
\text { Stein Beck } \\
\text { (1903) Wiede } \\
\text { Hough, } \\
\text { Wal } \\
\text { Stein B }\end{array}$ & $\begin{array}{l}(1758) \\
(1758) \\
9 \\
\text { (1903) } \\
\text { ann, (1830) } \\
898) \\
\text { cker, }\end{array}$ \\
\hline Calliphoridae & $\begin{array}{l}\text { Rhyncomya } \\
\text { nigripes }\end{array}$ & Séguy, (1933) & \\
\hline \multirow[t]{2}{*}{ Ulidiidae } & Physiphora alceae & $\begin{array}{l}\text { Preyssler, } \\
\text { (1791) }\end{array}$ & \\
\hline & $\begin{array}{l}\text { Physiphora } \\
\text { smaragdina }\end{array}$ & Loew, (1852) & \\
\hline \multirow[t]{2}{*}{ Sarcophagidae } & $\begin{array}{l}\text { Wohlfahrtia nuba } \\
\text { Chrysomya }\end{array}$ & $\begin{array}{l}\text { Wiedemann, } \\
\text { (1830) }\end{array}$ & Wiedemann, \\
\hline & putoria & -1830 & \\
\hline Stratiomyidae & Aspidacantha atra & Kertesz, (1916) & \\
\hline Psychodidae & Sand fly & & \\
\hline \multirow[t]{2}{*}{ Culicidae } & Culex sp. & & \\
\hline & Aedes sp. & & \\
\hline
\end{tabular}

\section{Discussion}

The camel trypanosomosis prevalence of $21.5 \%$ among camels examined by CATT during this study appeared lower than previous work (43.8\%) reported by El-Wathig and Faye (2013) in Al-Jouf, Northern Province, Saudi Arabia using the same method. The prevalence of trypanosomosis varies also according to the diagnostic test used. In a survey achieved in Chad (Delafosse and Doutoum, 2004), the apparent prevalence was six times lower (5.3\%) by using Buffy Coat Techniques than by using CATT (30.5\%), which appeared to over-estimate the true prevalence. Comparable result was reported in Egypt Abdel-Rady, [12] where a prevalence of $43.5 \%$ was observed with CATT test while Giemsa stain blood smears allowed detecting trypanosomes parasite in $4.1 \%$ of the camels, hematocrit centrifugation technique in $6.2 \%$, and by PCR in 56.9\%. In a recent survey in Saudi Arabia, Al-Afaleq et al. [13] reported a prevalence of $39.4 \%$ with CATT test vs $0.8 \%$ only with parasitological examination. This prevalence presented a high regional variability between 26 and $46 \%$ with the maximum in the Central Province corresponding to our area study. The differences observed in surveys achieved in the same areas could be attributed to variable practice of anti-trypanosomal drugs usage. Results of camels trypanosomosis prevalence investigated in Sudan by blood smear and CATT test gave $2.9 \%$ and between 20 to $30 \%$ respectively Elamin et al., [14] Adil et al., [15] Kenya Njiru et al., [16] or Ethiopia Zeleke and Bekele [17]. However, the pattern of prevalence of T. evansi differed also according to different location due to the ecology of study area which has a direct effect on the distribution of biting flies responsible for mechanical transmission of the parasite El-Wathig et al., [18]. The entomological study conducted in Al-Kharj area indicated that Stomoxys calcitrans and mosquitoes were the only biting fly species associated with camels during the study period. Although the NZI trap is very effective sampling device for tabanids Mihok et al.[5], no tabanid flies were caught during our capture campaign. This might be due to the intensive use of insecticides applied in stagnant water surfaces that serve as suitable breeding sites of tabanids, while the breeding sites of Stomoxys were not sprayed (dung mixed with soil). Moreover, the efficiency of the different flies in transmitting Trypanosoma evansi is reported to vary in different geographic conditions and is also dependent on the interval between two successive feeds and the intensity of the fly challenge Kassa et al. [19]. The peak was observed at the maximum seasonal activity of flies and mosquitoes during the more wet months of March-April in spring and October in autumn. The same finding was observed by Jacquit et al. [20] They reported that stable flies were highly adaptable and exploiting favorable climatic conditions between spring and late autumn for their outdoors activity. Indeed, when the temperature is suitable, relative humidity can influence the abundance and seasonal activity of biting flies, through effect on the availability of breeding sites Mellor et al., [21]. In our present study, high catches of flies were achieved from water station and people houses more than other sites. These findings are similar to the studies conducted by several authors who reported that stable flies are present in many habitats Grimaud [22]; Zinga et al. [23]; Bitome et al. [24]. The presence of stable flies is associated with unsanitary conditions and is more present in anthropic environments. The present results indicated that Stomoxys calcitrans may be an important mechanical vector of camel T. evansi in Al-Kharj area. Thus, the elimination of Stomoxys breeding sites may help in reducing the risk of contracting camel trypanosomosis although the prevention of the disease is based on medical treatment of camels rather to the control of biting flies Jilo et al. [25]. The role of mosquitoes in mechanical transmission of camel trypanosomosis should be considered. Despite having no report about the role of mosquitoes in the transmission of T. evansi 
in camel, they are potential vectors of trypanosoma sp. infection in birds' worldwide Votipka et al. [26-29].

\section{Conclusion}

The capture campaign did not confirm the dominant role of tabanids as potential insects in relation with the trypanosomosis transmission to camel in Al-Kharj region of Saudi Arabia. Rather, the Stomoxis calcitrans flies were the potential insects. since the capture was limited in time ( 9 months) and in places, further campaigns must be conducted to have a more precise view of the interactions between the disease and potential vectors.

\section{References}

1. Pacholek X, Gamatic D, Vias G, Tibayrenc R (2001) Prevalence of Trypanosoma evansi Trypanosomasis in young camels in west Niger. Rev Elev Med Vet pays Trop 44: 177-182.

2. Al Qarawi AA, Omar H M, Abdel Rahman H A, El Mougy S A, El Belely M S (2004) Trypanosomosis-induced infertility in dromedary (Camelus dromedarius) bulls: Changes in plasma steroids concentration and semen characteristics. Animal Reproduction of Science 84(1-2): 73-82.

3. Losos GJ (1980) Diseases caused by Trypanosoma evansi a review. Veterinary Research Communications 4: 165-181.

4. Luckins A G (1998) Trypanosomosis caused by Trypanosoma evansi in Indonesia. Journal of Protozoology Research 8: 144-152.

5. Mihok S, Carlson D A, Krafsur E S, Foil L D (2006) Performance of the Nzi and other traps for biting flies in North America. Bull Entomol Res 96(4): 387-397.

6. Schofield S, Witty C, Brady J (1997) Effects of carbon dioxide, acetone and 1-octen-3-ol on the activity of the stable fly, Stomoxys calcitrans. Physiol Entomol 22(3): 256-260.

7. Beresford D V, Sutcliffe J F (2008) Male stable fly (Stomoxys calcitrans) response to $\mathrm{CO} 2$ changes with age: Evidence from wind tunnel experiments and field collections. Journal of Vector Ecology 33(2): 247254.

8. Mihok S, Carlson D A, Ndegwa P N (2007) Tsetse and other biting fly responses to Nzi traps baited with octenol, phenols and acetone. Medical and Veterinary Entomology 21(1): 70-84.

9. Thrusfield M (2005) Veterinary Epidemiology 2nd ed Blackwell Science Ltd. UK.

10. Mihok S (2002) The development of multipurpose trap (the Nzi) for tsetse and other biting flies. Bulletin of Entomological Research 92: 385403.

11. Zumpt F (1973) The Stomoxyine Biting Flies of the World: Taxonomy Biology Economic Importance and Control Measures. Gustav Fisher Verlag Stuttgart.

12. Abdel Rady A (2008) Epidemiological studies (parasitological, serological and molecular techniques) of Trypanosoma evansi infection in camels (Camelus dromedarius) in Egypt. Vet World 1(11): 325-328.

13. Afaleq Al, Elamin E A, Fatani A, Homeida A G (2015) Epidemiological aspects of camel trypanosomosis in Saudi Arabia. J Camel Pract Res 22(2): 231-234

14. Elamin E A, El Bashir M O A, Saeed E M A (1998) Prevalence and infection pattern of Trypanosoma evansi in camels in mid-Eastern Sudan. Trop Anim Health Prod 30(2): 107-114.

15. Adil E A B, Adam D A, Mohammed S M, Mohammed AA (2018) Prevalence of Trypanosoma evansi in camels in four states of great Butana Sudan. International Journal of Zoology Studies 3(3): 33-37.

16. Adil E A B, Adam D A, Mohammed S M, Mohammed A A (2018) Prevalence of Trypanosoma evansi in camels in four states of great Butana Sudan. International Journal of Zoology Studies 3(3): 33-37.

17. Adil E A B, Adam D A, Mohammed S M, Mohammed A A (2018) Prevalence of Trypanosoma evansi in camels in four states of great Butana Sudan. International Journal of Zoology Studies 3(3): 33-37.

18. El Wathig M, Faye B, Thevenon S, Ravel S, Bossard G (2016) Epidemiological surveys of camel trypanosomosis in Al-jouf, Saudi Arabia based on PCR and ELISA. Emirates Journal of Food and Agriculture 28 (3): 212-216.

19. Kassa T, Tadesse E, Hassen C (2011) Prevalence of camel trypanosomosis and its vectors in Fentale district, South East Shoa Zone, Ethiopia. Vet Arhiv 81(5): 611-621.

20. Jacquit P, Rouet D, Bouhsira E, Salem A, Lienard E, etal. (2014) Population dynamics of Stomoxys calcitrans (Diptera: Muscidae) in southwestern France. Revue Méd Vét 165(9-10): 267-271.

21. Jacquit P, Rouet D, Bouhsira E, Salem A, Lienard E, etal. (2014) Population dynamics of Stomoxys calcitrans (Diptera: Muscidae) in southwestern France. Revue Méd Vét 165(9-10): 267-271.

22. Grimaud Y (2013) Stomoxes (Diptera: Muscidae) in Reunion Island: Biology ecology and control. GDS Meeting Reunion pp.1- 8 .

23. Zinga Koumba RC, Bouyer J, Mavoungou JF, Acapovi Yao GL, Kohagne TL (2013) Assessment of the diversity of haematophagous Diptera in a swampy clearing of Gabon using the Vavoua and Nzi traps. Rev Elev Med Vet Country Too 66: 91-96.

24. Bitome EP, Moncharmont FX, Mavoungou JF, Mba OR, Duvallet G (2015) Distribution and abundance of hematophagous flies (Glossinidae, Stomoxys, and Tabanidae) in two national parks of Gabon. Parasite 22: 25.

25. Jilo K, Nejash A, Golo D, Makida E (2017) Camel Trypanosomiasis: A review on past and recent research in Africa and Middle East. American Eurasian Journal of Scientific Research 12(1): 13-20.

26. Votipka J, Szabová J, Zidkova L, Svobodova M (2012) Trypanosoma culicavium sp nov an avian trypanosome transmitted by Culex mosquitoes. Int J System Evolut Microbiol 62: 745-775.

27. Delafosse A, Doutoum A (2004) Prevalence of Trypanosoma evansi infection and associated risk factors in camels in eastern Chad. Vet Parasitol 119(2-3): 155-164.

28. Wathig EI M, Faye B (2013) Surveillance of camel trypanosomosis in AlJouf Región, Saudi Arabia. Camel Int. J Vet Sci 1(1): 89-98.

29. Perry J N, Wall C, Greenway AR (1980) Latin square designs in field experiments involving sex attractants. Ecolog Entomol Soc S Afri 38: 341-396. 
(C) This work is licensed under Creative Commons Attribution 4.0 License To Submit Your Article Click Here: Submit Article

DOI: $10.32474 /$ CIACR.2020.08.000287

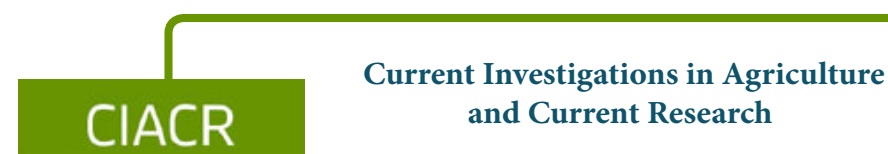

\section{Assets of Publishing with us}

- Global archiving of articles

- Immediate, unrestricted online access

- Rigorous Peer Review Process

- Authors Retain Copyrights

- Unique DOI for all articles 